\begin{tabular}{|c|c|}
\hline & Volume \& Issues Obtainable at The Women University Multan \\
Annals of Social Sciences and Perspective \\
ISSN: 2707-7063, Volume 1, No.2 December 2020
\end{tabular}

\title{
Stem Cell Tourism and International Trade of Unapproved Stem Cell Interventions
}

\author{
Sajid Ali ${ }^{1}$, Saif ur Rahman², Muhammad Khalid Anser ${ }^{3}$
}

\begin{abstract}
Nowadays, stem cell treatments for different medical situations are generally advertised through websites of different global hospitals and clinics. However, most stem cell treatments are clinically unapproved. This paper describes different features of the international trade of stem cell tourism, including the locality, risks and environmental regulations. Stem cell tourism is considered to be a subset of a far broader industry of stem cell interventions, which may be suitable in extraordinary conditions where the number of patients is small. However, the extensive trade and application of stem cell treatment in different countries does not give the affirmation of health gains to qualify as treatment and producing regulatory problems for the development of effective stem cell treatments and patient care. The governments should provide sufficient funding by supervising the public research programs and formulate new governance structures for coercive transnational activities related to international trade of unapproved stem cell interventions.
\end{abstract}

Keywords: Stem cell tourism; stem cell industry; international trade; stem cell treatment; unapproved stem cell interventions; health risks.

\section{Introduction}

Many diseases like Parkinson, Alzheimer, diabetes, cardiovascular diseases, epithelial diseases, strokes, burns and retinal problems are demanding diseases that became treatable with the use of stem cell interventions (Jaenisch et al., 2018). Human stem cells are used as the elements for treatment, which are explained as such kind of cells which have the ability to self-regeneration as well as the capacity to produce differentiated cells. Stem cell technology is both a revolution and an evolution in modern biomedicine (Weissman, Anderson \& Gage, 2001; Hawke et al., 2019). The marketing of unapproved stem cell therapies has become an international industry and it is different from other pharmaceuticals treatments in that they are dynamic and living, making it hard to assuring proper standardization and dosing. Contrary to pharmaceutical drugs, stem cells are not anticipated to be removed and metabolized from the body (Mcmahon, 2014; Hawke et al., 2019).

Traveling of patients abroad for stem cell treatment is called 'stem cell tourism. It is related to 'medical tourism' which implies travel to other regions for the treatment of illness (Petersen et al., 2017). However, it is different from medical tourism in some aspects.

\footnotetext{
${ }^{1}$ PhD Scholar, School of Business and Economics, Universiti Putra, Malaysia sajidali1136@gmail.com

${ }^{2} \mathrm{PhD}$ Scholar, School of Economics, Finance and Banking, Universiti Utara, Malaysia saifrao12@gmail.com

${ }^{3}$ Associate Professor, School of public administration, Xi, an University of Architecture and Technology,

China khalidsnnu@yahoo.com
} 
Medical tourism is mostly encouraged by shorter waiting times or lower costs for treatment abroad. On the other hand, stem cell tourism is inspired by hope, and the people are driven to obtain stem cell treatment because it is not allowed or offered in their home countries (Murdoch, 2010; Caulfield \& Murdoch, 2019). Stem cell treatments for different medical situations are currently advertised on various websites of hospitals and clinics in many countries (Ryan et al., 2010; Petersen \& Seear, 2011). Despite continuous health warnings by different scientific agencies (Australian Stem Cell Centre, 2009; ISSCR, 2008, 2012) that stem cell treatments are potentially harmful and clinically unproven, many patients travel abroad for these treatments (Ryan et al., 2010; Lomax, Torres, \& Millan, 2020).

\section{Role of Stem Cell Tourism in the Medical Travel Industry}

Stem cell tourism is considered a part of the global medical and travel industry which includes spa and wellness tourism, tourism for organ transplant, cosmetic and dental tourism, and reproductive tourism (Gharaibeh, Anderson \& Deasy, 2016). This sector contains, apart from the hospitals, doctors, supporting staff, and clinic themselves, marketing, insurance, several advisories, and 'concierge' services (e.g., pickup from airport and arranging accommodation), and conference and event management services, and travel agencies. It is an industry that governments have been determined to improve as an essential component for value-adding for the bioeconomy (Petersen \& Krisjansen 2015). The global industry of medical tourism was estimated at $\$ 10.5$ billion in 2012 and was expected to grow to $\$ 32.5$ billion by the year 2019, with an average growth rate of 18 percent annually (Bio Spectrum Asia, 2019). On the other hand, the stem cell market is projected to increase from $\$ 26$ billion in 2011 to $\$ 119$ billion in 2018 (Transparency Market Research, 2019).

Due to a lack of verifiable data and inconsistencies in the record of medical travel, it is hard to determine the exact number of patients who have traveled for medical treatment of any kind (Petersen et al., 2017). Currently, there is no method available for keeping the record of health travelers that would give a concept of the character and growth of the health tourism market. According to an estimate, 15 million patients have traveled across the borders and consumed $\$ 4500$ to 6500 per visit which includes treatment costs, inpatient stay, transport, and accommodation (Patients Beyond Borders, 2019). National Statistics of the United Kingdom, in 'International Passenger Survey' estimated that 250,000 patients of the country have traveled abroad for treatment in the year 2017 (IMTJ, 2018).

Stem cell tourism is an essential element of the growing industry of medical travel and global health and involves those interventions that are not clinically approved (Ormond \& Sulianti, 2017). A new method of stem cell treatment will be encouraged by evidence through proper experiments in clinics and gain approval from regulatory authorities, before it is accessible to the general public and eligible for obtaining funds through different medical schemes or health insurance (Timmermans \& Berg, 2003; Snyder \& Cohen, 2019). In biomedical science, for the approval of a new treatment method, a 'gold standard' of the evidence in the form of the better and systematic review and randomized double-blind control trial is needed which summarize the evidence from all clinical trials of a specific minimum quality standard (Cochrane, 2015; Sipp et al. 2017; Snyder \& Cohen, 2019).

\section{The Size of Global Stem Cell Market}

No one should be astonished by the fast-growing demand by consumers for stem cell treatments. For the past few years, stem cell technology has permanently motivated people to presume many health gains from the massive investments in this biomedical field (Datta, 
2018). Health demand for the consumer has been maintained and stimulated through a movement of positive media stories (McKay, 2000; Chan, 2017). Consumer health demand is further encouraged by consumer information through suppliers, like the information from stem cell technology itself is considered continuous and positive. Thus, consumer information is asymmetric and strengthening the commitments of stem cell technology (Lau et al. 2008).

These days, the online outlets, including private clinic or hospital websites, internet articles and patient blogs, give the primary foundation for the health consumer choice (Levine, 2010; Meehan et al., 2017). Many stem cell suppliers claim that their treatments offer an efficient and safe therapy for specific diseases while traditional and western medicines are unable to treat such kind of conditions. This type of information may be encouraged by soothing details about the certificate of the business (e.g., ISO 9001 and GMP), the registered clinical trials, the holding of patents, and the professionals who are working in advisory boards of companies (Sipp, 2011, Berger et al. 2016). In few cases, the information obtained for the process of innovation to support the therapy makes distinct the borderline between the clinical trials, clinical experimentation and clinical application by the use of the terms 'clinical use of stem cell treatment' and the 'experimental clinical application' and by replacing the term 'approved clinical trial' with 'approved experimentation for clinical application. (Qiu \& Zhai, 2009; Salter, Zhou \& Datta, 2017).

Table 1: Stem cell clinics in some selected countries

\begin{tabular}{|l|l|l|}
\hline Country & Number of Clinics & Number of Patients \\
\hline India $^{*}$ & $>45-50$ & $>10,000$ \\
\hline China** & $>400$ & $>50,000$ \\
\hline Japan*** & $>25$ & $>10,000$ \\
\hline Russia**** & $>100$ & $>20,000$ \\
\hline $\begin{array}{l}* \text { Lok Sabha (2017) } \\
\text { **Hu et al. (2018) } \\
* * * \text { Data taken from Munsie et al. (2017) }\end{array}$ & \\
\hline
\end{tabular}

\section{Demand for Stem Cell Therapies}

Not entirely but mostly, consumer demands for new and established healthcare forms have conventionally been conciliated with the help of doctor's role in defining the demand in the form of 'clinical need' (Salter, Zhou \& Datta, 2017). The 'hype and hope' of stem cell technology encouraged by a media has promoted huge expectations for consumers (Murdoch $\&$ Scott 2010). Many sources of websites (i.e., patient blogs, websites by private companies, and articles on the internet) give the main foundations for the choices of health consumers (Levine 2010). Suppliers of stem cells shrink the expectations of consumers, and demand is increased by their information and declarations that their therapies provide an efficient and safe therapy for specific ailments that conventional medicine considers as difficult or incurable to treat (Sipp, 2011). So, the information received by the consumer from suppliers persistently be asymmetric and strengthening the capabilities of stem cell technology (Lau et al. 2008; Salter et al., 2017). 
The limitations levied by a specific condition of disease, the presence of pain, and the constraints for local treatment are helpful to calculate the benefits and risks with its own values and rationality (Miller \& Joffe, 2009; Salter et al., 2015). It cannot be presumed that such demand by the consumer will act in a way compatible with the orthodox models in biomedical innovations. It may exhibit its own direction and logic demanding shorter periods of time in the access to innovation models and delivery of new treatments with the capability giving reaction accordingly (Park 2012; Blasimme 2013; Jaenisch et al., 2018). Like in other sectors of health, the disagreement between the stem cell demand and the limited supply may change into political demands of stem cell innovations for the delivery of new treatments. (Park 2012; Cyransoski 2013a; Cyranoski 2013b).

\section{Journeys of Stem Cell Tourists in Search of Hope}

Like other fields of biosciences, stem cell science relies on the expression of hope. Since the $20^{\text {th }}$ century, hope has been progressively used in the bio-industry for the advertisement of innovations and medical treatments like cord blood banking (Brown, 2005). While the hope is expressed and conveyed in different ways in national and international contexts, reflecting the popular cosmopolitan influences and popular medical cultures (Good, 1995). The delivery of hope penetrates biomedical and health practices and innovations in many modern societies (Petersen et al., 2017). We can see the immense proof of hope in many fields of health, mostly visible in the treatment of cancer with a positive and hopeful outlook as a source of motivator, resilience, and a mean for achieving recovery and overcoming adversity (Ehrenreich, 2009). Now a day, the benefits of fostering hope in health sectors have been encouraged by doctors and health professionals (Cutcliffe \& Herth, 2002; Eliott and Olver, 2007; Herth, 2008; Cutcliffe, 2009; Peterson et al., 2017).

Rose \& Novas (2005) and Novas (2006) have identified the importance of the debate of hope beyond the clinical trial for the efforts of citizens to affect the directions of science to accelerate the procedure by which treatments of different diseases are developed. The term 'political economy' was used to distinguish the form of activism through which the citizens are involved in attaining their goals. According to Rose \& Novas (2005), the internet has become an important tool to sustain the political economy of hope by fundraising, facilitating self-education, access to different direct-to-consumer resources, sharing of patient's experiences and attachment with other actors like researchers, media and politicians. This dominant feature of hope is evidently observable in the field of stem cell treatment, where health organizations sometimes create a lobby for taking funds for research on stem cell technology (Rose \& Novas 2005; Petersen, Seear \& Munsie, 2014).

Online advertisements for the stem cell treatments gives the apprehension that there is a lot of choice for the countries who offer such therapies which may be undertaken like fetal or adult stem cells, and the procedure based on human embryonic (Lau et al. 2008; Petersen \& Seear 2011). In some health institutes, stem cell tourism is often marketed in the form of packaged holidays, i.e., stem cell treatment along with recreation (Cornell, 2006). In some cases, these types of clinics are opened in foreign locations by offering sightseeing, sun and surf with therapeutic and recreational benefits (Gesler, 1992; Connell, 2006).

Different factors formed the decision about the destination of stem cell tourism. It includes quality of the treatment or trust in the provider, proficiency of clinicians in the English language at the treatment centre, value for money and online information on the success of such treatment (Brophy, 2017; Meskus, 2018). In a few cases, stereotypes and national comparison were noticeable for the decisions about destinations. When deciding between 
India and China, the former was considered a less invasive treatment because most people can speak English there (Petersen, Seear \& Munsie, 2014).

\section{Unproven Stem Cell Intervention and Health Risks}

The term stem cell tourism is used interchangeably with unapproved or experimental stem cell treatment. Stem cell interventions are referred to as stem cell therapies or treatments that are given in unknown potency in most applications of stem cell clinics (Sugarman, 2008). This term is often used for the tradition of "biotech pilgrimage" to prevent tourism-related implications (Song, 2010). As a primary feature of the practice, however, both biotech pilgrimage and stem cell tourism require travel, and the unapproved status of these interventions remains its vital feature (Matthews \& Iltis, 2016).

Stem cell tourism is considered to be a subset of a far broader industry of stem cell interventions, which are generally approachable to local inhabitants (Sipp et al., 2017). In China, many unapproved stem cell interventions refer to be local patients with little concern for health tourists. One of the famous stem cell clinics 'Wu Stem Cells Medical Center' of China declares that it has given treatment to 856 local patients between the years 2005 and 2011 (Ogbogu et al., 2013). Another study reports that patients in India also access Indianbased unapproved interventions and these types of interventions have also been available locally for the patients in the United States (Kaiser, 2012; DeFrancesco, 2012). Evidence shows that the activities of stem cell tourism which is known as a small subset of a big industry which is serving local or domestic patients and the information about the application of stem cell interventions on the domestic level is much difficult to acquire (Weiss et al., 2018).

There are considerable health risks linked with the application of unapproved stem cell treatment like infection, rejection, and death (Daley et al., 2016). Unfortunately, following the treatment, there is usually little to no follow-up and there is no reporting of side effects or adverse conditions because these interventions are unregulated, so complications resulting from such treatment remain unknown (Turner, 2015; Snyder, Turner \& Crooks, 2018).

\section{Unregulated International Trade of Stem Cell Treatment}

The low regulatory burdens and low operating costs afforded by online marketing techniques and treatment clinics, accompanied by massive potential of profit enabled by recruitment of patients from developed economies, has resulted in the fast development of stem cell industry, which is based on the under-or unregulated international trade of stem cell interventions (Berger et al., 2016; Sipp et al., 2017). More than 300 companies related to stem cell treatment are identified which are advertising in the English language (unpublished data). According to estimation, more than 100 stem cell clinics are operating in Russia, while a noted bioethicist claimed that more than 300 such clinics are presented in China as of 2013 (as shown in Table 1).

The geographical scope for unregulated trade of stem cell treatment is broad regarding patient recruitment, the location of treatment clinics and pre-treatment operations (McLean, Stewart \& Kerridge, 2015). Clinics for active treatment can be found in economies that have high regulations like United States ${ }^{4}$, Japan ${ }^{5}$, and Germany ${ }^{6}$, and also in emerging biomedical

\footnotetext{
${ }^{4}$ Stem Cell Rejuvenation Center. Phoenix, AZ, USA. http://www. stem-cell-center.com/

${ }^{5}$ Clinic O. Tokyo, Japan. http://www.odaclinic.net/

${ }^{6}$ XCell-Center. Köln/Düsseldorf, Germany. http://www.xcell-center. com/
} 
countries like China ${ }^{7}$ and India ${ }^{8}$. Although data about the patients and their countries of origin are not available but we can access it from the review of blogs by different patients and testimonials like 'China Stem Cell News' who claimed that patients travel from various locations in Europe, Middle East, North America and Asia9 .

The scale of growth and rapidity of pseudo-medical uses and unregulated trade of stem cells has induced considerable criticism by media organizations, bioethicists, and academic societies (Dodson \& Levine, 2015). Researchers have claimed that there is a lack of scientific-based research for the claims made on the websites related to stem cell treatment, patient blogs, analysis of media accounts, summaries of the challenges about regulations, and the overviews of the scope of stem cell trade and its evolution into alternative medicine (Lau et al., 2008; Zarzeezny et al., 2010; Sipp, 2011; Rosemann, 2017). Organizations representing the research related to stem cell treatment have regularly issued information resources or statements of concern about prospective patients ${ }^{10}$.

There are various regulatory responses for stem cell treatment in different countries around the world. Some countries have been able to close down or prohibit the opening of clinics that offer stem cell care within their jurisdictions, such as the Netherlands, Hungary, and Costa Rica (Sheldon, 2007). Other countries, including China and Thailand, have imposed regulations to place oversight requirements and limitations on clinical applications of stem cell treatment, but all such laws and enforcement appears to be unsuccessful, provide the continuous online existence of stem cell clinics in these countries (Sirisunthon \& Sarnsamak, 2009). In both Japan and Germany, the preference given to a doctor's decision on the use of stem cells that have not been subjected to clinical trials has created de facto loopholes in medical care legislation in these economies that enable such clinics to operate in relative dispensation (Kawakami et al. 2010). Law enforcement is also insufficient in the United States where many stem cell hospitals or clinics are operational in the southern borders, and these clinics have ready access to their partner clinics in Mexico ${ }^{11}$ and the Caribbean ${ }^{12}$, and many clinics also claim to provide treatments domestically ${ }^{13}$.

Confusion over the government's view of stem cell clinics and companies that offer unapproved therapies has also created a complication in Asian countries, where public investment in stem cell research has emphasized the application of basic science in advance (Sipp, 2009). Beike Biotechnology, in China, made partnerships with many municipal, military and provincial hospitals and declared it had earned million dollars as a government grant $^{14}$. Geeta Shrooff's NuTech MediWorld clinic in India has received intensive funding from some senior government officers, at least one of whom is claimed to have received her proprietary human embryonic stem (ES) medication. This lack of clarity and uniformity in a government position has resulted in the violation of laws by firms and a cause of the impression of legitimacy which could affect the decisions of patients about such health treatments (Patra \& Sleeboom, 2010; Rosemann et al., 2017).

\footnotetext{
${ }^{7}$ Biotechnology B. Shenzhen, China. http://www.beikebiotech.com/

${ }^{8}$ Chaitanya Stem Cell Center, Pune, India. http://www.chaitanyastemcell.com/

${ }^{9}$ China Stem Cell News. http//www.stemcellschina.com

${ }^{10}$ Closer Look at Stem Cells http//www.closerlookatstemcells.org/

${ }^{11}$ Progencell. San Diego, CA, USA. http://www.progencell.com/

${ }^{12}$ Regenocyte. Bonita Springs, FL, USA. www.regenocyte.com

${ }^{13}$ Stem Cell Rejuvenation Center. Phoenix. AZ. USA. http://www.stem-cell-center.com/

${ }^{14}$ Biotechnology B. Patient Information Guide Summer, 2010. Accessed at:http://beikebiotech.com/information/BeikeInformation-Guide.pdf
} 


\section{Conclusion and Public Policy Implications}

Nowadays, stem cell treatments for different medical situations are generally advertised through websites of different global hospitals and clinics. However, most stem cell treatments are clinically unapproved. Despite many cautions from health practitioners and scientists about the side effects of such health treatments, still many people are ready to take the risk. This paper has described different features of the global industry of stem cell tourism, including the locality, risks and environmental regulations in which such unapproved stem cell interventions are sold. Stem cell tourism is considered to be a subset of a far broader industry of stem cell interventions, which may be suitable in extraordinary conditions where number of patients is small. The widespread application of stem cell therapy, however, does not produce the empirical evidence to allow research, nor gives the affirmation of health gains to qualify as treatment, producing regulatory and ethical problems for the development of effective stem cell treatments and patient care.

Unproven stem cell therapies, including infection, rejection and death, have led to serious complications. However, governments should determine whether these interventions have any advantages. Without evidence of the safety and effectiveness given by large clinical trials, it would be difficult to determine the benefits of these therapies for patients. Although clinical trials are slow and costly, in order to inform evidence-based medical practise, they remain the best way to produce precise results. The governments should provide sufficient funding by supervising the public research programs related to stem cell interventions and struggle to reconcile the expectation and excitement linked with the medical advancement with the realities of what and when they are able to deliver new and effective treatments of stem cell interventions. Stem cell treatments should, however, be both effective and safe and established in such a way as to ensure respect for human participants and patients.

The countries should demonstrate national home-keeping policies to enable translational stem cell applications by following the guidelines of international organizations like the International Society for Stem Cell Research (ISSCR). As an empirical tool, the concept calls for attention to how countries devise stem cell policies to express circumstances at home with global regulatory patterns through locally accessible political and regulatory frameworks. The governments can use different kinds of trials and provision for stem cell studies to change the status of local and national regulation, to develop legislative clauses to make spaces for experimentation, and accelerate marketing pathways for stem cell products. The implementation of measures that guarantee the protection and quality of stem cell bioproducts is another challenging problem. It is also important to take into account the ethics of acquisition of the biological material from which stem cells are derived, including the safeguarding of the women rights who are the main sources of umbilical cord blood.

Another important issue relating to the misrepresentations about the benefits of stem cell treatment can contribute to criminal fraud. Patients are not responsible for such potentially adverse activities, and the duty for taking curative measures remains with governments. This is not easy, as the mistakes occur beyond the territorial jurisdiction of the state, so it is important to establish the revolutionary form of transnational governance. Stem cell therapies are also affected by internet scams that sell questionable products related to health care, ranging from counterfeit pharmaceuticals to fake cancer cures. The ISSCR guidelines assert that health authorities of the countries should perform their duty to take disciplinary measures against the concerned practitioners and also to close illegal clinics where illegitimate therapies are offered (ISSCR, 2008). Proactive coordination between law enforcement authorities and those assigned to investigate cybercrime and international crime must be 
necessary. Cross-border medical tourism is an emergent phenomenon that requires countries to abandon territorial sovereignty and formulate new governance structures and accountability for coercive transnational activities.

\section{References}

Amariglio, N., Hirshberg, A., Scheithauer, B. W., Cohen, Y., Loewenthal, R., Trakhtenbrot, L., \& Toren, A. (2009). Donor-derived brain tumor following neural stem cell transplantation in an ataxia telangiectasia patient. PLoS medicine, 6(2), e1000029. doi:10.1371/journal. pmed.1000029

Berger, I., Ahmad, A., Bansal, A., Kapoor, T., Sipp, D., \& Rasko, J. E. (2016). Global distribution of businesses marketing stem cell-based interventions. Cell stem cell, 19 (2), 158-162.

BioSpectrum Asia. (2019). Medical tourism market to reach $\$ 32.5$ bn globally in 2019: Report.

AcademicOneFile.http://go.galegroup.com/ps/i.do?id=GALE\%7CA347329322\&v=2. $1 \& \mathrm{u}=$ monash $\& \mathrm{it}=\mathrm{r} \& \mathrm{p}=\mathrm{AONE} \& \mathrm{sw}=\mathrm{w} \& \mathrm{asid}=\mathrm{a} 2 \mathrm{ed} 676 \mathrm{eb} 3 \mathrm{e} 9 \mathrm{~b} 03 \mathrm{~b} 1 \mathrm{~b} 89622 \mathrm{fa} 5 \mathrm{ee} 2 \mathrm{abb}$.

Blasimme, A. (2013). Translating stem cells to the clinic: Scientific societies and the making of regenerative medecine. Quaderni. Communication, technologies, pouvoir, (81), 2944.

Brophy, J. (2017). Navigating the 'grey areas': Australian medical travellers in China's stem cell bionetwork. Asia Pacific Viewpoint, 58(2), 216-227.

Brown, N., (2005) Shifting tenses, reconnecting regimes of truth and hope, Configurations, 13(3), 331- 55 .

Murdoch, C. E., \& Scott, C. T. (2010). Stem cell tourism and the power of hope. The American Journal of Bioethics, 10(5), 16-23.

Caulfield, T., \& Murdoch, B. (2019). Regulatory and policy tools to address unproven stem cell interventions in Canada: the need for action. BMC medical ethics, 20(1), 51.

Chan, S. (2017). Current and emerging global themes in the bioethics of regenerative medicine: the tangled web of stem cell translation. Regenerative medicine, 12(7), 839851.

Cochrane. (2015). When and how to update systematic reviews. http://www. cochrane.org/MR000023/METHOD_when-and-how-to-update- - systematic-reviews .

Connell, J. (2006). Medical tourism: Sea, sun, sand and... surgery. Tourism management, 27(6), 1093-1100.

Cutcliffe, J. R. (2009). Hope: the eternal paradigm for psychiatric/mental health nursing. Journal of Psychiatric and Mental Health Nursing, 16(9), 843-847.

Cutcliffe, J., \& Herth, K. (2002). The concept of hope in nursing 2: hope and mental health nursing. British Journal of Nursing, 11(13), 885-893.

Cyranoski, D. (2010). Korean deaths spark inquiry, Nature, 468- 485.

Cyranoski, D. (2012). Stem-cell therapy takes off in Texas: a boom in unproven procedures is worrying scientists. Nature, 483(7387), 13-15.

Cyranoski, D. (2013). Cowboy culture. Nature, 494, 166-168

Daley, G. Q., Hyun, I., Apperley, J. F., Barker, R. A., Benvenisty, N., Bredenoord, A. L., \& Heslop, H. E. (2016). Setting global standards for stem cell research and clinical translation: the 2016 ISSCR guidelines. Stem cell reports, 6(6), 787-797.

Datta, S. (2018). Emerging dynamics of evidence and trust in online user-to-user engagement: the case of 'unproven'stem cell therapies. Critical Public Health, 28(3), 352-362.

DeFrancesco, L. (2012). Adult stem cell therapies walk the line. Nature Biotechnology, 30(8), $739-741$. 
DelVecchio Good, M. J. (1995). Cultural studies of biomedicine: an agenda for research. Social Science \& Medicine, 41(4), 461-473.

Dobkin, B. H., Curt, A., \& Guest, J. (2006). Cellular transplants in China: observational study from the largest human experiment in chronic spinal cord injury. Neuro rehabilitation and neural repair, 20(1), 5-13.

Dodson, B. P., \& Levine, A. D. (2015). Challenges in the translation and commercialization of cell therapies. BMC biotechnology, 15(1), 70-77.

Radlett, M. (2011). Smile or Die: How Positive Thinking Fooled America and the World. Existential Analysis, 22(1), 186-191.

Eliott, J. A., \& Olver, I. N. (2007). Hope and hoping in the talk of dying cancer patients. Social Science \& Medicine, 64(1), 138-149.

L Freeman (2003). State medical board revokes license of stem cell doctor Zannos Grekos, naplesnews.com.

Gesler, W.M. (1992). Therapeutic landscapes, medical issues in light of the new cultural geography. Social Science \& Medicine, 34(7), 735-746.

Gharaibeh, B., Anderson, J. E., \& Deasy, B. M. (2016). Combating the threat of stem cell tourism through patient education and government regulation. Innovation and entrepreneurship in health, 3, 15-24.

Hawke, B., Przybylo, A. R., Paciulli, D., Caulfield, T., Zarzeczny, A., \& Master, Z. (2019). How to peddle hope: an analysis of YouTube patient testimonials of unproven stem cell treatments. Stem cell reports, 12(6), 1186-1189.

Herth, K. (2008). Enhancing hope in people with a first recurrence of cancer, Journal of Advanced Nursing, 32(6), 1431-1441.

IMTJ (International Medical Travel Journal) (2018). The latest fact about medical tourism. http://www.imtj.com/articles/2018/internet-facts-on-medical-tourism-40205/ Accepted 17 Aug 2015.

F Jabr (2012). In the flesh: The embedded dangers of untested stem cell cosmetics, Sci Am at https://www.scientificamerican. com/article.cfm?id=stem-cell-cosmetics

Hu, L., Zhao, B., \& Wang, S. (2018). Stem-Cell Therapy Advances in China. Human gene therapy, 29(2), 188-196.

International Society for Stem Cell Research (ISSCR). (2008). Guidelines for clinical translation of Stem Cells. Available at: http://www.isscr.org/clinical trans/pdfs/ISSCRGLClinicalTrans.pdf

Jaenisch, R., Dubois, N., Rasko, J. E., Deng, H., Alvarado, A. S., Fuchs, E., ... \& Baldwin, K. (2018). Challenging Stem Cells, 173, 1063-1065.

Kaiser, J. (2012). Texas Medical Board Approves Rules for Controversial Treatment. Science, 336, 284-284.

Kawakami, M., Sipp, D., \& Kato, K. (2010). Regulatory impacts on stem cell research in Japan. Cell Stem Cell, 6(5), 415-418.

Kirstin, R.W., and Ana, S.I. (2017). Unproven Stem Cell-Based Interventions. Texas Heart Institute Journal, 44(3), 171-173.

Lau, D., Ogbogu, U., Taylor, B., Stafinski, T., Menon, D., \& Caulfield, T. (2008). Stem cell clinics online: the direct-to-consumer portrayal of stem cell medicine. Cell stem cell, 3(6), 591-594.

Levine, A. D. (2010). Insights from patients' blogs and the need for systematic data on stem cell tourism. The American Journal of Bioethics, 10(5), 28-29.

Lok Sabha. (2017) Government of India, Ministry of Health and Family Welfare, Lok Sabha, Unstarred Question No. 3448. 
Lomax, G. P., Torres, A., \& Millan, M. T. (2020). Regulated, reliable, and reputable: Protect patients with uniform standards for stem cell treatments. Stem Cells Translational Medicine, 9(5), 547-553.

Mendick,R \& Hall,A. (2011). Europe's largest stem cell clinic shut down after death of baby. Telegraph. co. uk.

Meskus, M. (2018). Human Cells to the Market. Craft in Biomedical Research, Palgrave Macmillan, New York, 45-77.

McKay, R. (2000). Stem cells-hype and hope. Nature, 406 (6794), 361-364.

McMAHON, D. S. (2014). The global industry for unproven stem cell interventions and stem cell tourism. Tissue Engineering and Regenerative Medicine, 11(1), 1-9.

Matthews, K. R., \& Iltis, A. S. (2016). Unproven Stem Cell Interventions and Encouraging Collaboration between Regulators and Desperate Patients. Poster, Baker Institute for Public Policy, Baker Hall MS-40, Suite 120, Houston, TX 77005.

McLean, A. K., Stewart, C., \& Kerridge, I. (2015). Untested, unproven, and unethical: the promotion and provision of autologous stem cell therapies in Australia. Stem cell research \& therapy, $6(1), 33$.

Meehan, D., Bizzi, I. H., \& Ghezzi, P. (2017). Stem cell therapy on the Internet: using Google to analyze public expectations and treatment. Frontiers in ICT, 4, 1-10.

Miller, F. G., \& Joffe, S. (2009).Limits to research risks.Journal of medical ethics, 35 (7), 445-449.

Morrison, M. (2012). Promissory futures and possible pasts: The dynamics of contemporary expectations in regenerative medicine. BioSocieties, 7(1), 3-22.

Munsie, M., Lysaght, T., Hendl, T., Tan, H. Y. L., Kerridge, I., \& Stewart, C. (2017). Open for business: a comparative study of websites selling autologous stem cells in Australia and Japan. Regenerative medicine, 12(7), 777-790.

Murdoch, C. E., \& Scott, C. T. (2010). Stem cell tourism and the power of hope. The American Journal of Bioethics, 10(5), 16-23.

Novas, C. (2006). The political economy of hope: Patients' organizations, science and biovalue. BioSocieties, 1(3), 289-305.

Ogbogu, U., Rachul, C., \& Caulfield, T. (2013). Reassessing direct-to-consumer portrayals of unproven stem cell therapies: is it getting better? Regenerative medicine, 8(3), 361369.

Park, M. (2012). Texas board approves rules on use of stem cells. The New York Times, April, 13, 2012.

Patients Beyond Borders. (2019). Medical tourism statistics and facts. Patients Beyond Borders . http://www.patientsbeyondborders.com/medical-tourismstatistics-facts

Patra, P. K., \& Sleeboom-Faulkner, M. (2010). Bionetworking: between guidelines and practice in stem cell therapy enterprise in India. SCRIPTed, 7 (2), 295-310.

Petersen, A., \& Krisjansen, I. (2015). Assembling "the bioeconomy": Exploiting the power of the promissory life sciences. Journal of Sociology, 51 (1), 28-46.

Petersen, A., MacGregor, C., \& Munsie, M. (2016). Stem cell miracles or Russian roulette?: patients' use of digital media to campaign for access to clinically unproven treatments. Health, Risk \& Society, 17(7-8), 592-604.

Petersen, A., Munsie, M., Tanner, C., MacGregor, C., \& Brophy, J. (2017). Hopeful Journeys of Stem Cell Tourists. In Stem Cell Tourism and the Political Economy of Hope, Palgrave Macmillan, London, 83-100.

Petersen, A., Munsie, M., Tanner, C., MacGregor, C., \& Brophy, J. (2017). Stem cell tourism and the political economy of hope. Springer. 
Petersen, A., Munsie, M., Tanner, C., MacGregor, C., \& Brophy, J. (2017). 'Choice', Hope, and Stem Cell Treatments. In Stem Cell Tourism and the Political Economy of Hope, Palgrave Macmillan, London, 31-57.

Lau, D., Ogbogu, U., Taylor, B., Stafinski, T., Menon, D., \& Caulfield, T. (2008). Stem cell clinics online: the direct-to-consumer portrayal of stem cell medicine. Cell stem cell, 3(6), 591-594.

Rose, N. and Novas, C. (2005) Biological citizenship. In Ong, A. and Collier, S.J. (eds) Global Assemblages, Technology, Politics, and Ethics as Anthropological Problems. Malden: Blackwell.

Rosemann, A. (2017). Challenges to international stem cell clinical trials in countries with diverging regulations. In Safety, Ethics and Regulations, Springer, Cham, 301-319.

Ryan, K. A., Sanders, A. N., Wang, D. D., \& Levine, A. D. (2010). Tracking the rise of stem cell tourism. Regenerative Medicine, 5(1), 27-33.

Salter, B., Zhou, Y., \& Datta, S. (2015). Hegemony in the marketplace of biomedical innovation: Consumer demand and stem cell science. Social Science \& Medicine, 131, 156-163.

Salter, B., Zhou, Y., \& Datta, S. (2017). Governing new global health-care markets: the case of stem cell treatments. New Political Economy, 22(1), 76-91.

Sipp, D. (2011). Stem cell stratagems in alternative medicine. Regenerative medicine, 6(3), 407-414.

Sipp, D., Caulfield, T., Kaye, J., Barfoot, J., Blackburn, C., Chan, S., \& Sleeboom-Faulkner, M. (2017). Marketing of unproven stem cell-based interventions: A call to action. Science translational medicine, 9 (397), eaag0426.

Sipp, D., Caulfield, T., Kaye, J., Barfoot, J., Blackburn, C., Chan, S., ... \& SleeboomFaulkner, M. (2017). Marketing of unproven stem cell-based interventions: A call to action. Science translational medicine, 9(397), eaag0426.

Sirisunthon, S., \& Sarnsamak, P. (2009). Medical Council issues new decree to control stem cell research. The Nation. Bangkok, Thailand, 29.

Snyder, J., Turner, L., \& Crooks, V. A. (2018). Crowd funding for Unproven Stem CellBased Interventions. Jama, 319(18), 1935-1936.

Snyder, J., \& Cohen, I. G. (2019). Medical Crowdfunding for Unproven Medical Treatments: Should Gofundme Become a Gatekeeper?. Hastings Center Report, 49(6), 32-38.

Lyn, T. E. (2013). China stem cell therapies offer heartbreak for many. Reuters 2011. http://www.reuters.com/article/2011/09/21/us-stemcell-scamsidUSTRE78K18120110921

Thirabanjasak, D., Tantiwongse, K., \& Thorner, P. S. (2010). Angiomyeloproliferative lesions following autologous stem cell therapy. Journal of the American Society of Nephrology, 21(7), 1218-1222.

Timmermans, S., \& Berg, M. (2003). The gold standard: The challenge of evidence based medicine and standarization in health care. Philadelphia: Temple University Press.

Transparency Market Research (2019). New Stem Cells Market Report Published by Transparency Market Research. PR Web. 24 July. Available at: http://www. prweb.com/releases/prweb10960023.htm (accessed 31.03.20).

Turner, L. (2015). US stem cell clinics, patient safety, and the FDA. Trends in molecular medicine, 21(5), 271-273.

Ogbogu, U., Du, L., Rachul, C., Bélanger, L., \& Caulfield, T. (2013). Chinese newspaper coverage of (unproven) stem cell therapies and their providers. Stem Cell Reviews and Reports, 9(2), 111-118.http://www.ncbi.nlm.nih.gov/pubmed/ 23292462

Qiu, R. Z., \& Zhai, X. M. (2009). On the ethical supervision and control of stem cell research and clinical application. Chinese Medical Ethics, 22(5), 3-9. 
Ormond, M., \& Sulianti, D. (2017). More than medical tourism: lessons from Indonesia and Malaysia on South-South intra-regional medical travel. Current Issues in Tourism, 20(1), 94-110.

Petersen, A., \& Seear, K. (2011). Technologies of hope: Techniques of the online advertising of stem cell treatments. New Genetics and Society, 30 (4), 329-346.

Petersen, A., Seear, K., Munsie, M., (2014). Therapeutic journeys: the hopeful travails of stem cell tourists. Sociology of Health and Illness, 36 (5), 670-685.

Sheldon, T. (2007). The Netherlands bans private stem cell therapy. BMJ: British Medical Journal, 334(7583), 12.

Sina. (2013). The Mess of Stem Cell Treatment. http://news.sina.com.cn/c/sd/2013-09 07/105725122461.html

Sipp, D. (2009). Stem cell research in Asia: a critical view. Journal of cellular biochemistry, 107(5), 853-856.

Sipp, D. (2011). The unregulated commercialization of stem cell treatments: a global perspective. Frontiers of medicine, 5 (4), 348-355.

Song, P. (2010). Biotech pilgrims and the transnational quest for stem cell cures. Medical Anthropology, 29(4), 384-402.

Weissman, I. L., Anderson, D. J., \& Gage, F. (2001). Stem and progenitor cells: origins, phenotypes, lineage commitments, and transdifferentiations. Annual review of cell and developmental biology, 17(1), 387-403.

Zarzeczny, A., Rachul, C., Nisbet, M., \& Caulfield, T. (2010). Stem cell clinics in the news. Nature biotechnology, 28(12), 1243-1246. 